\title{
DETEKSI BRUCELLOSIS PADA SAPI PERAH PERANAKAN FRIESIAN HOLSTEIN DI KECAMATAN PAGU KABUPATEN KEDIRI
}

\author{
Bagus Uda Palgunadi ${ }^{1}$, Roeswandono ${ }^{1}$, Adilla Luthfita Fa' ${ }^{1}{ }^{1}$, Ady Kurnianto ${ }^{\text {* }}$ \\ ${ }^{1}$ Fakultas Kedokteran Hewan, Universitas Wijaya Kusuma Surabaya \\ *Email: adykurniantodvm@gmail.com
}

\begin{abstract}
Brucellosis (Keluron disease) is a strategic infectious disease with zoonotic potential, one of which is genus Brucella abortus. This research aims to detect Brucellosis in dairy cattle FH in Pagu District, Kediri Regency. This research uses two serological tests, namely the Rose Bengal Test (RBT) and the Complement Fixation Test (CFT) with descriptive analysis method. 30 cattle blood samples were taken from the coccigea vein. The blood was set aside at room temperature to form a serum. The serum that has been obtained is taken to the Department of Food and Livestock of Kediri Regency for checking the RBT. The remaining serum obtained was sent to BBVet Wates for CFT examination. The results obtained show negative results on both tests. But one of the samples with the code $S 9$ had gone through an abortion. This might occur due to other factors such as genetic disorders, the presence of viruses such as $B V D$, toxic agents and live vaccines during pregnancy.
\end{abstract}

Keywords: Brucellosis, Dairy Cattle Friesian Holstein, RBT, CFT

\section{PENDAHULUAN}

Setiap tahun tingginya permintaan bahan pangan asal ternak, menyebabkan meningkatnya usaha ternak sapi perah di Indonesia. Seiring dengan jumlah penduduk yang bertambah, dengan pendapatan perkapita masyarakat yang tinggi dan menyebabkan kesadaran akan susu dan daging sebagai sumber protein hewani (Andaruisworo dan Solikin, 2015). Hewan ternak memiliki beragam jenis penyakit, sehingga memerlukan wawasan tentang gejala penyakit yang mungkin akan terjadi agar dilakukannya pengobatan dan pengendalian secara seksama (Winarsih, 2018). Sepanjang proses produksi dan budidaya peternakan, diperlukan kewaspadaan akan terjadinya suatu penyakit. Jawa Timur dikenal sebagai gudang ternak, sehingga wajib untuk menjaga produk ternak yang dihasilkan berupa produk yang Aman, Sehat, Utuh, dan Halal (ASUH).

Menurut Winarsih (2018) Penyakit hewan ternak adalah gangguan kesehatan yang disebabkan oleh kelainan genetik, gangguan metabolisme, trauma, toksisitas, infeksi parasit, proses degeneratif, prion, dan mikroorganisme pathogen.

Penyakit Keluron (Brucellosis) merupakan penyakit menular strategis dikarenakan penularannya relatif cepat antar daerah dan lintas batas serta diperketat pengaturan lalu lintas ternak. Bakteri genus Brucella ini dikategorikan sebagai penyakit zoonosis serta diklasifikasikan sebagai mikroorganisme kelompok BSL III (Biosafety level 3) (Syah, dkk., 2011). Penularan Bruellosis dapat melalui kontak langsung pada hewan, dan juga mengkonsumsi produk dari susu, sehingga dikategorikan sebagai penyakit zoonosis (Dwi, dkk., 2018). Infeksi pada manusia terutama disebabkan B. melitensis B. abortus dan B. melitensis, melalui interaksi langsung dengan hewan yang terinfeksi dan menggunakan produk yang terkontaminasi, seperti susu dan daging dsb (Ali, et al., 2018).

Spesies Brucella merupakan penyebab penyakit Brucellosis, yang merupakan pathogen bakteri gram negatif fakultatif intraseluler spesies vertebrata termasuk manusia. Bakteri ini bersifat gram negatif, kecil, aerob, berbentuk cocobacilli, non motil, dan tidak menghasilkan spora (Mugabi, 2012). 
Menurut Novita (2016) Indonesia belum bebas Brucellosis, terutama daerah yang mayoritas beternak sapi perah. Sebagian besarnya belum melakukan pemusnahan terhadap sapi perah yang terbukti positif Brucellosis, sehingga sapi penderita bersifat carrier seumur hidupnya di lokasi tersebut.

Penelitian ini bertujuan untuk mendeteksi penyakit Brucellosis pada sapi perah peranakan FH di Kecamatan Pagu Kabupaten Kediri dengan menggunakan metode Complement Fixation Test (CFT) dan Rose Bengal Test (RBT).

\section{MATERI DAN METODE}

Penelitian dilakukan di peternakan daerah Kecamatan Pagu Kabupaten Kediri sebagai tempat pengambilan sampel darah. Pengambilan sampel darah sebanyak $5 \mathrm{ml}$ dengan jumlah 30 ekor sapi perah. Uji RBT dilakukan di laboratorium Kesmavet Dinas Ketahanan Pangan dan Peternakan Kabupaten Kediri dan uji CFT dilakukan di Balai Besar Veteriner Wates Yogyakarta.

\section{Pengambilan darah}

Alat dan bahan untuk pengambilan darah adalah tabung venoject, jarum venoject G12, handle (thorax), desinfektan, kapas, akuades steril dan alkohol. Sampel diambil pada vena jugularis atau vena coccigea menggunakan tabung vacutainer yang dilapisi silicon. Setelah itu, diamkan pada suhu kamar hingga kental dan membentuk serum atau disentrifugasi. Pengambilan secara aseptis agar terhindar dari kontaminasi bakteri yang tidak diinginkan. Alat yang digunakan pada laboratorium harus dalam kondisi steril.

\section{Prinsip Uji RBT}

Reaksi ini membentuk pengikatan antigen Brucella sp. yang sudah dilemahkan serta diwarnai dengan antibodi dari serum. Pada permukaan antigen terjadi pengikatan dengan antibodi menimbulkan reaksi teraglutinasi, jika non reaktif maka, tidak ada antibodi dalam serum.

\section{Prosedur Uji RBT}

Serum dan antigen Brucella RBT diambil dari mesin pendingin lalu diamkan selama $1 / 2$ 1 jam pada suhu ruangan. $30 \mu 1$ serum yang telah di koleksi diteteskan pada plate dan dicampur dengan antigen Brucella dengan jumlah yang sama, sehingga percampurannya membentuk diameter sebesar $2 \mathrm{~cm}$. Serum dan antigen tadi dicampur menggunakan pengaduk (rotary aglutinartor), kemudian plate digoyang goyangkan dengan tangan selama 4 menit dan akan terlihat proses aglutinasi jikan serum mengandung antibodi Brucella. Tingkat aglutinasi disesuaikan dengan kriteria: $0=$ tidak terjadi aglutinasi, $+=$ aglutinasi hanya sedikit, $++=$ aglutinasi terlihat sebagian, $+++=$ aglutinasi terlihat sangat jelas (Novita, dkk., 2016).

\section{Prinsip Uji CFT}

Complement Fixation Test adalah reaksi pengikatan komplemen, juga direkomendasikan sebagai uji penyaringan (screening) brucellosis pada populasi ternak dan secara individual (Mujiatun, dkk., 2016). Prinsip reaksi ini menyebabkan lisisnya sel darah merah, dikarenakan adanya antibodi dan antigen kompleks yang homolog menarik komplemen, sehingga berikatan dengan antibodi di bagian Fc (Astarina, 2017).

\section{Prosedur Uji CFT}

Prosedur CFT sebagai berikut: Menggunakan microplate 96 well dengan dasar U. Pada baris A1-A10 microplate diisi dengan serum sampel sebanyak $50 \mu \mathrm{l}$, tambahkan kontrol serum positif pada baris A11 dan baris A12 kontrol serum negatif. Kemudian serum diinaktivitaskan pada suhu $58^{\circ} \mathrm{C}$ selama 30 menit. Pada semua sumur diisikan pelarut CFT

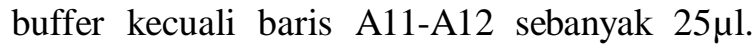
Lalu dilakukan pengenceran seimbang, $25 \mu \mathrm{l}$ serum diambil dari baris A dipindahkan ke baris B lalu dikocok beberapa kali dan seterusnya dilakukan sampai baris H. Semua sumur di baris $\mathrm{C}-\mathrm{H}$ diisikan Antigen sebanyak $25 \mu \mathrm{l}$. Tambahkan $25 \mu 1$ komplemen di semua sumur (baris B-H), lalu tambahkan pelarut CFT buffer sebanyak $25 \mu$ pada semua sumur baris B (sebagai kontrol positif aktivitas antikomplemen). Plat ditutup menggunakan selotip, kemudian inkubasi selama 30 menit dengan suhu $37^{\circ} \mathrm{C}$. Setelah itu dilepas (penutup), tambahkan $25 \mu \mathrm{l}$ sel yang disensitisasi di semua sumur, lalu kocok dengan microshaker selama 45 menit, baca reaksinya (Kartini, dkk., 2017). 


\section{HASIL}

Wilayah pengambilan sampel berada di Kecamatan Pagu Kabupaten Kediri. Pemilihan kandang atau peternak hasil dari diskusi dengan pengurus koperasi unit desa setempat serta tenaga medis yang akan membantu di lapangan. Lalu melakukan wawancara dengan peternak tentang gejala klinis dan riwayat vaksinasi. Total sampel yang didapatkan adalah 30 darah, kemudian menjadi serum untuk diuji dengan uji RBT dan CFT. Hasil dari penelitian ini 30 serum sapi diuji dengan metode Rose Bengal Test (RBT) dan Complement Fixation Test (CFT). Dapat dilihat pada Tabel 1 dan Tabel 2.

Tabel 1. Hasil Pemeriksaan RBT

\begin{tabular}{ccc}
\hline $\begin{array}{c}\text { Jumlah } \\
\begin{array}{c}\text { Serum } \\
\text { Sapi }\end{array}\end{array}$ & $\begin{array}{c}\text { Negatif } \\
\text { RBT }\end{array}$ & $\begin{array}{c}\text { Positif } \\
\text { RBT }\end{array}$ \\
\hline 30 & 30 & 0 \\
\hline
\end{tabular}

Tabel 2. Hasil Pemeriksaan CFT

\begin{tabular}{ccc}
\hline $\begin{array}{c}\text { Jumlah } \\
\text { Serum } \\
\text { Sapi }\end{array}$ & $\begin{array}{c}\text { Negatif } \\
\text { CFT }\end{array}$ & $\begin{array}{c}\text { Positif } \\
\text { CFT }\end{array}$ \\
\hline $\mathbf{3 0}$ & 30 & 0 \\
\hline
\end{tabular}

Hasil RBT ini dibaca dengan melihat adanya aglutinasi pada plate. Dikatakan positif jika adanya butiran pasir (aglutinasi), jika negatif maka tidak teraglutinasi. Dari semua sampel, kode S9 memiliki gejala klinis abortus. Pada pemeriksaan ini, 30 serum didapatkan hasil negatif. Dapat dilihat pada Gambar 1.

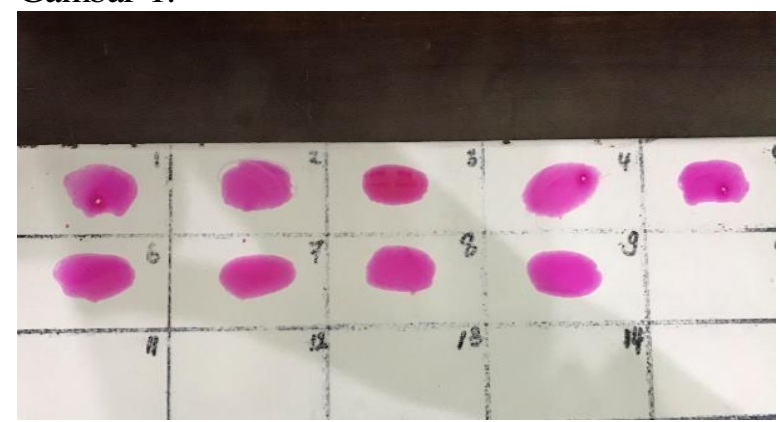

Gambar 1. Hasil Pemeriksaan RBT

\section{PEMBAHASAN}

Pada pengujian CFT didapatkan hasil negatif, ditunjukkan pada lubang microplate tidak ada endapan pada dasar sumur, hemolisis sempurna serta cairan warna merah muda. Berdasarkan hasil pengujian 30 sampel dengan metode Rose Bengal Test dan memiliki gejala abortus, namun menunjukkan hasil negatif pada dua metode ini. Pada pemeriksaan RBT didapatkan hasil negatif, menurut Besung, dkk., (2015) hasil positif terbagi menjadi tiga kriteria yaitu teraglutinasi ringan $(+)$, teraglutinasi sedang $(++)$ dan teraglutinasi sempurna $(+++)$. Tetapi pada hasil pemeriksaan yang didapatkan tidak memenuhi kriteria diatas. Pada uji CFT juga menunjukkan hasil negatif, Amanitin (2012) menjelaskan bahwa hasil positif ditandai dengan titer $1 / 4$ atau lebih dan tidak terjadi lisis pada sel darah domba, terdapat endapan eritrosit dan cairan berwarna bening. Pada pemeriksaan ini juga tidak memenuhi kriteria tersebut. Dapat disimpulkan bahwa semua sampel di daerah kecamatan Pagu bebas Brucellosis.

Ketika melakukan wawancara ke peternak, pemilik memberitahu bahwa salah satu sapinya pernah mengalami abortus. Setelah di uji, sapi ini memiliki hasil negatif. Penyebab terjadinya abortus selain brucellosis, ada factor lainnya menurut Horvingh (2009)yaitu kelainan genetic pada janin yang dapat menyebabkan aborsi tidak sering didiagnosis dan Complement Fixation Test menunjukkan hasil negatif. Salah satu dari sampel yang di dapatkan biasanya terjadi pada sapi individu. Kelainan ini, yang mungkin tidak menyebabkan perubahan pada penampilan luar janin, dapat mengakibatkan aborsi karena janin yang tumbuh tidak memiliki kemampuan untuk berkembang dengan baik dalam uterus. Heat stress juga dapat mempengaruhi kinerja reproduksi sapi perah, meskipun umumnya akan menyebabkan masalah konsepsi daripada aborsi. Sementara ada beberapa bukti yang menunjukkan bahwa peningkatan yang sangat mendadak dalam suhu lingkungan dapat mengakibatkan aborsi, ada sedikit bukti mendukung bahwa stres panas sebagai penyebab umum aborsi. Kejadian langka juga terjadi seekor sapi mengalami demam yang sangat tinggi dan dapat mengalami keguguran janin nya. Agen toksik juga dapat menyebabkan abortus atau kematian embrio awal. Sapi rentan terhadap pupuk nitrit dan nitrat atau nitrat yang ditemukan pada tanaman di bawah kondisi 
tertentu (misalnya kekeringan-stres). Jika seekor sapi terpapar dengan tingkat nitrat/nitrit yang cukup tinggi ( . 55\% atau lebih besar nitrat dalam hijauan), abortus dapat terjadi, terutama pada akhir kehamilan.

Horvingh (2009) menyebutkan ada beberapa virus yang dapat menyebabkan abortus salah satumya Bovine Viral Diarrhea virus (BVD). Virus ini memiliki berbagai macam sindrom penyakit pada sapi dan setelah virus ini beredar, dapat menjangkau janin melalui plasenta. Bakteri penyebab selain Brucella abortus adalah Streptococcus spp., Leptospira spp. Pemberian vaksin hidup modifikasi selama kehamilan termasuk faktor terjadinya abortus. Dimaksud vaksin hidup adalah vaksin yang dimodifikasi mengandung virus hidup atau bakteri yang di ubah untuk mencegah mereka menyebabkan penyakit klinis selagi merangsang sistem kekebalan tubuh.

Azzahrawani, dkk., (2018) menjelaskan, keadaan lingkungan yang tercemar mampu menimbulkan adanya faktor penyakit dan mudahnya penularan secara kontak langsung. Populasi ternak dan manajemen pemeliharaan termasuk faktor yang berhubungan dengan infeksi Brucellosis. Faktor resikonya seperti lapangan gembala, lalu lintas, lingkungan dengan kelembapan tinggi dan parit. Bakteri ini mampu bertahan hidup dalam beberapa bulan dalam jerami, air, lumpur, fetus abortus dan perlatan, serta dalam kondisi kering pun dapat bertahan hidup dalam debu dan tanah. Saat mengamati dilapangan, kondisi kandang cukup baik. Sapi tidak di gembala, tepat di belakang sapi ada tumpukan pupuk organik, sebelah kandang terdapat tempat pembuangan sisa feses dan urin. Ditemukan juga sisa tumpukan pakan yang tegenang dengan air. Bisa disimpulkan dengan kondisi kandang tersebut kemungkinan bisa terjadinya Brucellosis atau faktor penyakit lainnya. Perlunya pemeriksaan Brucellosis pada sapi perah peranakan Friesian Holstein penting untuk dilakukan, karena guna mengantisipasi adanya penularan pada hewan lainnya dan manusia.

\section{KESIMPULAN}

Berdasarkan hasil penelitian pada sapi perah peranakan Friesian Holstein di Kecamatan Pagu Kabupaten Kediri dapat disimpulkan bahwa tidak ditemukan adanya Brucellosis.

\section{REFERENSI}

Ali, S., Nawaz Z, Akhtar A, Aslam R, Zahoor M.A. and Ashraf M., 2018. Epidemiological Investigation of Human Brucellosis in Pakistan. Jundisapur J Microbiol. 11(7):1-5.

Amanitin. 2012. Kajian Infeksi Brucella abortus Pada Sapi Perah Menggunakan Uji Serologik dan Polymerase Chain Reaction (PCR). [M.Si. Tesis]. Institut Pertanian Bogor.

Andaruisworo, S. dan N. Solikin, 2015. Pendapatan Usaha Peternakan Sapi Perah Rakyat Di Kecamatan Ngancar Kabupaten Kediri. Modernisasi. 11(3):110.

Astarina, D.K., 2017. Penggunaan Immunostik Sebagai Uji Cepat Serologik Untuk Melacak Brucella abortus Pada Sapi. [M.Si. Tesis]. Institut Pertanian Bogor.

Azzahrawani, N., E. Martalina, S. Herman dan A. Abdillah. 2018. Investigasi Outbreak Bovine Brucellosis di Pulau Bengkalis Tahun 2018. Proc. of the 20th FAVA CONGRESS \& The 15th KIVNAS PDHI, Bali Nov 1-3, 2018. 390-392.

Besung, I.N.K., Suwiti N.K dan Suarjana I.G.K., 2015. Seroedpidemiologi Brucellosis Pada Sapi Bali di Nusa Tenggara Barat Sebagai Upaya Deteksi Dini Kejadian Penyakit. Seminar Nasional Sains dan Teknologi. 1-8.

Dwi, W.K, Tyasningsih W, Praja R.N., Hamid I.S., Sarudji $S$ dan Purnama M.T.E., 2018. Deteksi Antibodi Brucella pada Sapi Perah di Kecamatan Purwoharjo Kabupaten Banyuwangi dengan Metode Rose Bengal Test (RBT). Jurnal Medik Veteriner. 1(3):142-147.

Horvingh, E., 2009. Common Causes of Abortions. Virginia Cooperation Extension. Pp. 404-288.

Kartini, D., Noor S.M dan Pasaribu F.H., 2017. Deteksi Brucellosis Pada Babi Secara Serologis dan Molekuler di 
Rumah Pototng Hewan Kapuk, Jakarta dan Ciroyom, Bandung. Acta Veterinaria Indonesiana. 5(2):66-73.

Mugabi, R., 2012. Brucellosis Epidemiology, Virulence Factors, Control and Molecular Targets to Prevent Bacterial Infectious Diseases. [M.Sc. Thesis]. North Dakota State Univ.

Mujiantun., Soejoedono R.N. Sudarnika E dan Noor S.M., 2016. Deteksi Spesies Brucella pada Kambing di Rumah Potong Hewan Jakarta.Jurnal Sain Veteriner 34(2) : 172-181.

Novita, R., 2016. Brucellosis: Penyakit Zoonosis Yang Terabaikan. Pusat Penelitian dan Pengembangan Biomedis dan Teknologi Dasar Kesehatan. 12(2):135-140.

Novita, R., Hananto M, Sembiring M.M., Noor S.M., Kambang S, Lilian dan Khairirie, 2016. Seroprevalensi Ancaman Brucella abortus Pada Pekerja Peternakan Sapi Perah Kecamatan Ciwatu, Garut. Jurnal Kesehatan Reproduksi. 7(3):210-216.

Syah, S.P., E. Saswiyanti dan I.S. Nurhayati, 2011.Brucellosis di Indonesia.https:// docplayer.info/53843933- Brucellosis-diindonesia.html.

Winarsih, W.H., 2018. Penyakit Ternak yang Perlu Diwaspadai Terkait Keamanan Pangan. Cakrawala. 12(2):208-221 